\title{
Peramalan Bisnis Unit Usaha Syariah PT ABC dalam Tantangan Spin Off
}

\author{
Tatang Nurhidayat \\ Institut Tazkia Bogor \\ tatang.nurhidayat@gmail.com
}

\begin{abstract}
Spin off is separation of the sharia unit into a new company independent from its conventional parent. Spin off is a strategic issue for sustainability and development of Islamic financial institutions including Sharia Insurance. Independence and focus on the spin off process are positive. However, the economies of scale for stability and sustainable growth become challenges. The problem observed in this study is the ability of the general insurance sharia business unit to fulfill the spin off obligation as mandated in the Insurance Act number 40 of 2014. This Act stated that at the latest in 2024 it has to be spinned off by submitting a business plan to OJK no later than 2020. This study use Time Box Box method-Jenkins (ARIMA). The results of this study are expected to be consideration factor and information for General Insurance Companies, especially PT ABC, in determining the spin off business plan using forecasting.
\end{abstract}

Keywords: spin off, sharia business unit, insurance, forecasting, ARIMA

\begin{abstract}
ABSTRAK
Spin off atau pemisahan Unit Usaha Syariah menjadi perusahaan yang terpisah dari induk (konvensional) merupakan isu strategis dalam keberlangsungan dan pengembangan Lembaga Jasa Keuangan Syariah, termasuk Asuransi Syariah. Kemandirian dan fokus atas proses spin off menjadi hal positif, namun skala ekonomi untuk stabilitas dan pertumbuhan berkelanjutan menjadi tantangannya. Permasalahan yang diamati dalam penelitian ini adalah kemampuan Unit Usaha Syariah PT ABC dalam memenuhi kewajiban spin off sebagaimana diamanatkan dalam Undang-undang Perasuransian nomor 40 tahun 2014 yaitu paling lambat tahun 2024 dengan pengajuan rencana bisnis ke OJK paling lambat tahun 2020. Dengan menggunakan metode Runtun Waktu Box-Jenkins (ARIMA) diharapkan dapat menjadi bahan pertimbangan atau acuan bagi Perusahaan dalam pengambilan keputusan khususnya dalam penentuan rencana bisnis spin off.
\end{abstract}

Kata kunci: spin off, unit usaha syariah, asuransi, peramalan, arima 


\section{A. PENDAHULUAN}

Unit Usaha Syariah (UUS) terbukti mampu menjadi salah satu motor penggerak dalam perkembangan Lembaga Jasa Keuangan Syariah di Indonesia. Antusiasme Lembaga Jasa Keuangan cukup tinggi dalam ikut serta mengembangkan bisnis syariah melalui pembukaan UUS baik di Perbankan, Asuransi maupun Perusahaan Pembiayaan. Dalam perkembangannya, beberapa UUS telah melakukan pemisahan diri atau spin off menjadi perusahaan terpisah yang dalam industri Asuransi dikenal dengan istilah Perusahaan Asuransi Syariah (PAS).

Terkait dengan model bisnis antara UUS dan PAS, terdapat perdebatan diantara para pelaku usaha Asuransi Syariah, apakah lebih efektif tetap berupa UUS atau spin off menjadi PAS. Namun demikian, dengan berlakunya UndangUndang Republik Indonesia Nomor 40 tentang Perasuransian pada tanggal 17 Oktober 2014 sebagai pengganti UndangUndang Nomor 2 tahun 1992 tentang Perasuransian, perdebatan itu sudah tidak relevan mengingat regulator sudah memutuskan bahwa UUS Perasuransian wajib spin off menjadi PAS paling lambat 10 tahun sejak diundangkan yaitu paling lambat 17 Oktober 2024. Sejak tanggal tersebut maka tidak ada lagi UUS Perasuransian di Indonesia. Hal inilah yang menjadi tantangan bagi UUS Perasuransian untuk dapat mempersiapkan diri sehingga dapat melanjutkan usaha syariahnya dengan berhasil spin off atau malah tutup dan mentransfer portofolionya ke PAS lain. Adapun Pasal terkait kewajiban spin off tersebut terdapat pada Pasal 87 dalam Ketentuan Peralihan Bab XVII.

Menindaklanjuti amanat UU tersebut, OJK mengeluarkan Peraturan OJK no.67/POJK.05/2016 tentang Perizinan Usaha dan Kelembagaan Perusahaan Asuransi dan Perusahaan Asuransi Syariah. Dalam POJK ini, beberapa pasal yang terkait dengan spin off unit syariah diantaranya:

1. Modal minimum Perusahaan Asuransi Syariah sebesar 100 miliar Rupiah (Pasal 6), sedangkan Perusahaan hasil spin off harus mempunyai ekuitas minimum 50 miliar rupiah (Pasal 19).

2. Kewajiban menyusun rencana kerja spin off kepada OJK yang mendapat persetujuan RUPS, memuat cara, tahap pelaksanaan dan jangka waktu. 
Paling lambat 17 Oktober 2020 (Pasal 17 ayat 7$)$.

3. Spin off dapat dilakukan dengan mendirikan Perusahaan baru atau pengalihan seluruh portofolio kepesertaan ke PAS lain (Pasal 18).

4. Spin off dapat dilakukan oleh satu atau lebih unit syariah (Pasal 20).

Berdasarkan data Asosiasi Asuransi Syariah Indonesia (AASI), sampai tahun 2020, terdapat 59 Asuransi syariah yang terdiri atas 7 Perusahaan Asuransi Jiwa Syariah, 5 Perusahaan Asuransi Umum Syariah, 1 Perusahaan Reasuransi Syariah, 21 UUS Perusahaan Asuransi Jiwa, 22 UUS Perusahaan Asuransi Umum serta 3 UUS Perusahaan Reasuransi. Jumlah UUS Perasuransian sangat banyak dan masih mendominasi, sehingga kemampuan UUS untuk spin off sangat berdampak terhadap perkembangan Perasuransian Syariah.

PT ABC merupakan salah satu perusahaan Asuransi Umum yang mempunyai UUS sejak tahun 2007. Kontribusi premi UUS PT ABC termasuk ke dalam kategori pertengahan bersama 6 UUS lainnya yaitu dengan kontribusi premi diantara dua puluh milyar rupiah sampai dengan di bawah seratus milyar rupiah. Pemilihan UUS PT ABC dalam penelitian ini melihat indikator keuangan dimana posisinya berada di kategori pertengahan diantara UUS Asuransi Umum lainnya sehingga dapat menjadi gambaran bagi UUS yang lain yang lebih besar, relatif sama maupun lebih kecil.

\section{B. TINJAUAN PUSTAKA}

Islam sebagai agama yang sempurna senantiasa mendorong umatnya untuk maju, tumbuh, dan berkembang. Kemajuan umat Islam di segala bidang akan mengubah suatu peradaban. Demikian pula pada ekonomi Islam, perkembangan ekonomi Islam di Indonesia yang ditandai dengan tumbuh pesatnya industri keuangan syariah baik perbankan syariah maupun lembaga keuangan syariah memberikan solusi umat Islam untuk hijrah dari industri keuangan konvensional menuju industri keuangan syariah yang bersih dari unsur riba, gharar, maisir, haram, dan zalim.

Pembahasan ini fokus pada upaya UUS untuk melakukan spin off atau memisahkan diri dari perusahaan asuransi konvensional menjadi PAS. Sesungguhnya upaya ini sangat berdampak signifikan bagi perkembangan perasuransian syariah di Indonesia. Hal tersebut didukung oleh Undang-Undang Republik Indonesia Nomor 40 tentang 
Perasuransian pada tanggal 17 Oktober 2014. Dengan demikian diharapkan sebelum tanggal 17 Oktober 2024 UUS pada perusahaan asuransi konvensional berubah menjadi PAS.

\section{METODE PENELITIAN}

Dalam penelitian ini penulis menggunakan metode penelitian kuantitatif, dengan menggunakan metode Runtun Waktu Box-Jenkins (ARIMA) diharapkan dapat menjadi bahan pertimbangan atau acuan bagi Perusahaan dalam pengambilan keputusan khususnya dalam penentuan rencana bisnis spin off. Berdasarkan latar belakang masalah metode ini dirasa sangat tepat untuk memecahkan rumusan masalah penelitian, sehingga hasilnya dapat dijadikan acuan bagi UUS melakukan spin off yang tentunya sangat berdampak pada perkembangan perasuransian syariah di Indonesia.

\section{HASIL DAN PEMBAHASAN}

Penelitian ini menggunakan data berdasarkan laporan bulanan Unit Syariah PT ABC kepada Otoritas Jasa Keuangan (OJK) periode Januari 2011 sampai dengan Maret 2018. Peramalan dilakukan untuk melihat proyeksi kondisi variable uji yang meliputi Ekuitas, Kontribusi Premi dan Surplus Underwriting Dana Tabarru. Sebelum peramalan dengan ARIMA, masing-masing variable data dilakukan identifikasi melalui uji stasioneritas dan plot ACF, Penaksiran parameter model serta pemeriksaan diagnostic. Setelah peramalan, dilakukan cross validation.

1) Ekuitas

Variable Ekuitas bertujuan untuk melihat kemampuan perusahaan dalam memenuhi ketentuan ekuitas minimum spin off. POJK nomor 67/POJK.05/2016 tentang Perizinan Usaha dan Kelembagaan pasal 19, menjelaskan bahwa PAS hasil spin off wajib memiliki ekuitas minimum 50 Milyar Rupiah. Ketentuan ini sifatnya insentif mengingat ketentuan dasarnya pada aturan permodalan pasal 6 , pendirian baru PAS wajib memiliki modal minimum 100 Milyar Rupiah. Oleh karena itu, ketentuan modal PAS hasil spin off minimum harus mempersiapkan ekuitas sebesar 50 milyar rupiah, dengan tetap mempertimbangkan kemampuan modal 100 milyar rupiah.

Selain ketentuan minimum sebagaimana diatur dalam POJK, perlu juga dipersiapkan cadangan ekuitas dengan nilai tertentu, sehingga apabila 
terjadi kerugian yang menyebabkan penurunan ekuitas tidak langsung menyebabkan ekuitas dibaawah ketentuan minimum yang dipersyaratkan. Hal ini penting mengingat apabila ekuitas dibawah ketentuan minimum, harus dilakukan penyetoran modal baru atau menghadapi kemungkinan penghentian kegiatan usaha oleh OJK.

Berdasarkan data hasil peramalan ekuitas, dapat diamati bahwa peramalan ekuitas menunjukan kenaikan disetiap bulannya dari posisi Desember 2017 sebesar Rp 96,98 milyar serta pada bulan maret 2018 sebesar Rp 98,2 milyar menjadi Rp 115,6 milyar pada desember 2019. Apabila dihitung dalam persentase pertumbuhan maka pertumbuhan ekuitas dari tahun 2017 ke tahun 2018 sebesar $8,99 \%$. Sementara itu, pertumbuhan ekuitas selama 2 tahun diproyeksikan sebesar 19,23\%. Adapun diagram Ekuitas setelah peramalan adalah sebagai berikut :

Diagram 1. Ekuitas dan Peramalan Ekuitas

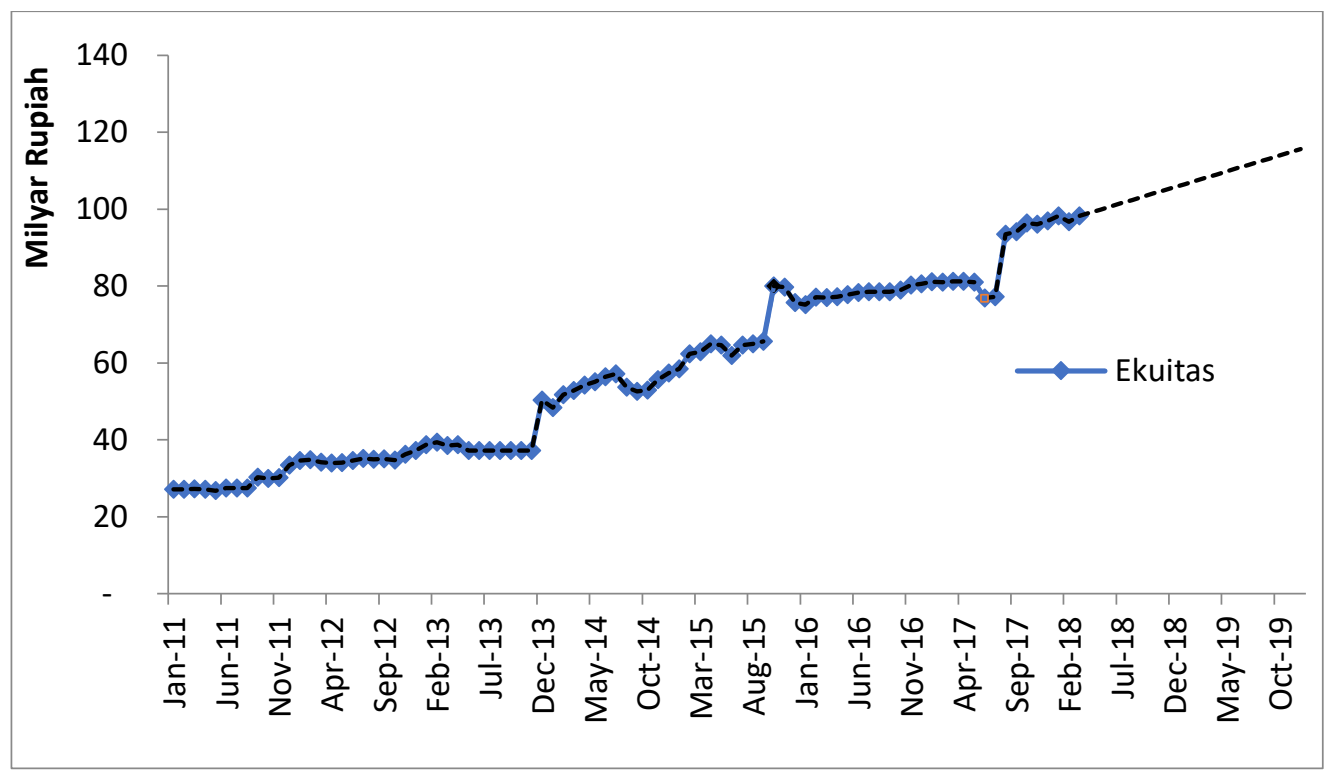

Berdasarkan cross validation dapat diamati bahwa peramalan ekuitas mempunyai nilai MAD Rp 1,32 milyar atau MAPE 1,34\%. Nilai tersebut menunjukan bahwa validitas model peramalan cukup tinggi.
Hasil peramalan ekuitas menunjukan tren positif dan pertumbuhan secara konsisten dimana pada akhir 2019 diproyeksikan bahwa ekuitas Unit Syariiah PT ABC mencapai Rp 115.627.945.774,-. Atas dasar ini maka 
ketentuan minimum ekuitas dapat dipenuhi oleh UUS untuk dapat melakukan spin off. Bahkan masih ada sejumlah ekuitas yang dapat ditambahkan sebagai cadangan serta pengembangan bisnis.

\section{2) Kontribusi Premi}

Kontribusi premi adalah adalah iuran atau sejumlah uang yang dibayarkan oleh Peserta kepada Pengelola yang sebagian darinya untuk dikelola sebagai Dana Tabarru' dan sebagian lainnya sebagai Ujrah untuk Pengelola sesuai dengan Akad Wakalah bil Ujrah. Berdasarkan pengertian tersebut, kontribusi premi sangat penting peranannya bagi perusahaan sebagai pendapatan baik bagi ujroh untuk pengelolaan perusahaan maupun sebagai dana tabarru untuk mengelola risiko yang diperjanjikan. Dengan spin off, selain modal yang harus ditingkatkan tentu berdampak pula pada peningkatan Biaya Management baik fix cost maupun variable cost.

Industri Asuransi merupakan industry yang high regulated dimana terdapat banyak aturan-aturan yang harus dipenuhi selain ketentuan dalam Undang-Undang Perseroan. Hal ini termasuk pada sumberdaya manusia yang sangat mempengaruhi fix cost. Sebagai contoh, selain kewajiban adanya Dewan Direksi dan Dewan Komisaris, ditentukan juga direksi-direksi khusus yang harus dijabat dan tidak boleh dirangkap oleh direksi lainnya. Sebagai gambaran, Fungsi yang harus ada paling tidak meliputi minimal 3 orang Direktur (terdiri atas Keuangan, Teknik \& Pemasaran), Komisaris \& Komisaris Independen, Dewan Pengawas Syariah, Komite Audit, Komite Investasi, Komite Management Risiko, Komite Penngembangan Produk, Aktuaris Perusahaan, Tenaga Ahli, Internal Auditor, Klaim \& Pelayanan, Pemasaran \& Pengembangan, serta Fungsi lain yang diperlukan perusahaan.

Berdasarkan data hasil peramalan Kontribusi Premi, dapat diamati bahwa peramalan menunjukan kenaikan pendapatan kontribusi premi sehingga total kontribusi premi pada tahun 2018 adalah $\mathrm{Rp}$ 37,64 milyar dan pada tahun 2019 menjadi Rp 47,36 milyar. Proyeksi pertumbuhan kontribusi premi tahun 2017 ke tahun 2018 sekitar Rp 5,9 milyar atau 18,54\% yaitu dari $\mathrm{Rp} 31,75$ milyar menjadi Rp 37,64 milyar. Dalam 2 tahun sampai dengan tahun 2019 diproyeksikan pertumbuhan kontribusi premi sebesar Rp 15,6 milyar atau 49,16\%. Adapun diagram 
kontribusi premi setelah peramalan adalah sebagai berikut:

Diagram 2. Kontribusi Premi dan Peramalan Kontribusi Premi

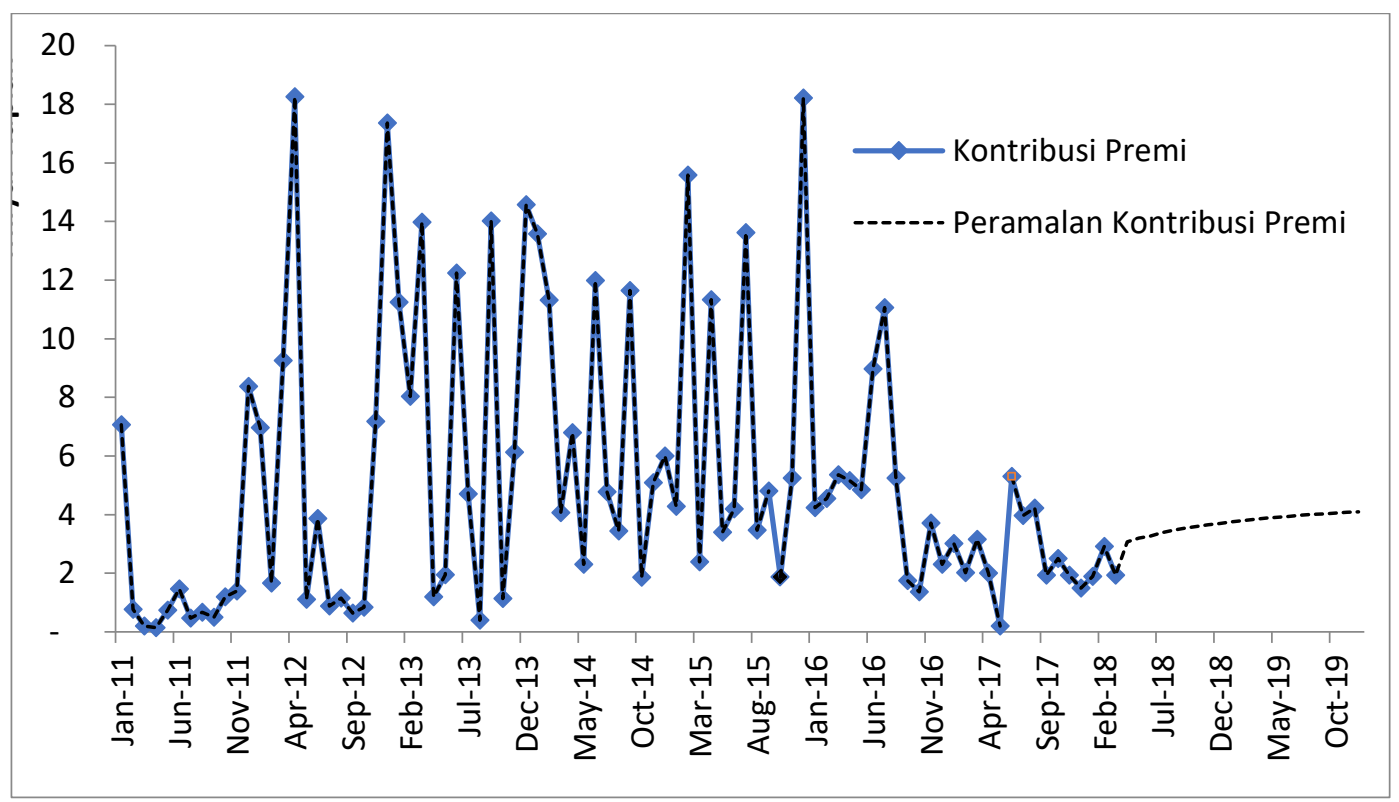

Berdasarkan cross validation, peramalan kontribusi premi mempunyai nilai MAD Rp 408,9 juta atau MAPE $14,46 \%$. Nilai tersebut menunjukan bahwa validitas model peramalan masih rendah. Hal ini sangat mungkin terjadi mengingat Fluktuasi kontribusi bulanan sangat tinggi pada tahun 2012 sampai dengan 2016. Fluktuasi ini bisa diakibatkan oleh beberapa hal diantaranya adanya kontribusi korporasi atau satu account/polis dengan nominal kontribusi premi yang sangat besar dimana tidak terjadi lagi pada tahun 2016 sampai 2018 atau Kkntribusi premi belum mencapai bilangan besar (large number) sehingga belum stabil dan masih memungkinkan untuk naik/turun dengan selisih yang besar.

Dalam menganalisis kebutuhan kontribusi premi akan dilakukan perbandingan dengan PAS yang sudah beroperasional sebagai tolak ukur (benchmark). PAS dimaksud adalah yang bergerak dalam lini bisnis Asuransi umum sebagaimana PT ABC. Saat ini terdapat 5 PAS yang bergerak di lini Asuransi Umum Syariah yaitu PT Asuransi Takaful Umum, PT Asuransi Chubb Syariah, PT Asuransi Jasindo Syariah, PT Asuransi 
Sonwelis Takaful serta PT Asuransi Askrida Syariah.

Atas kelima PAS tersebut, tidak seluruhnya dijadikan benchmark mengingat beberapa kondisi. PT Asuransi Takaful Umum tidak beroperasional pada tahun buku 2016 dan 2017 akibat penghentian kegiatan usaha, PT Asuransi Askrida Syariah baru beroperasional pada akhir tahun 2017 serta PT Asuransi
Sonwelis Takaful merupakan hasil konversi dari Asuransi konvensional. Oleh karena itu, yang dijadikan benchmark hanya PT Asuransi Chubb Syariah dan PT Asuransi Jasindo Syariah. Berdasarkan publikasi Laporan Keuangan Tahunan, ringkasan kondisi keuangan kedua perusahaan tersebut adalah sebagaimana disajikan dalam table berikut:

Tabel 1. Ringkasan Laporan Keuangan PAS (dalam jutaan)

\begin{tabular}{|c|c|c|c|c|}
\hline \multirow{2}{*}{ Variabel } & \multicolumn{2}{|c|}{ Chubb Syariah } & \multicolumn{2}{|c|}{ Jasindo Syariah } \\
\hline & 2016 & 2017 & 2016 & 2017 \\
\hline Kontribusi Premi & 83,666 & 89,407 & 129,523 & 136,539 \\
\hline Ujroh & 37,444 & 40,482 & 60,758 & 50,208 \\
\hline Beban Usaha & 41,488 & 40,350 & 52,404 & 57,655 \\
\hline Akuisisi\&Pemasaran & 18,629 & 15,612 & & \\
\hline Beban Umum & 22,859 & 24,738 & & \\
\hline Laba (Rugi) & $(4,679)$ & $(8,509)$ & 12,722 & 3,753 \\
\hline Surplu UW Tabarru & 5,857 & 1,446 & 4,066 & 4,233 \\
\hline
\end{tabular}

Dalam beban usaha, terdapat Beban Umum dan Beban Akuisisi. Beban umum didominasi oleh beban pegawai, gedung, peralatan kantor dan lain sebagainya yang pada umumnya merupakan fix cost. Sementara beban Akuisisi biasanya berupa persentase dari kontribusi sehingga menjadi variable cost.
Pada table diatas, Beban Umum Chubb Syariah pada tahun 2017 mencapai 24,7 milyar rupiah. Sementara di laporan keuangan tahunan Jasindo, tidak ada pembagian beban usaha. Namun apabila mengamati laporan kwartal 1 2018, menunjukan bahwa beban umum jasindo syariah sebesar 6,5 milyar rupiah. Dengan asumsi beban sama besar untuk setiap 
kwartal, maka beban umum tahunan berkisar di angka 26 milyar rupiah. Apalagi apabila memperhitungkan pembayaran THR serta kemungkinan kenaikan tahunan efektif di kwartal 2, tentu beban umum tahunan dapat lebih besar lagi. Dengan pendekatan ini menggambarkan bahwa fix cost kedua perusahaan besarannya tidak terlampau jauh berbeda walaupun dengan pendapatan premi yang cukup jauh berbeda.

Atas dasar fix cost yang tidak jauh berbeda, dapat diestimasikan kebutuhan atas kontribusi premi yang dapat dijadikan acuan untuk keberlangsungan perusahaan. Dari laba kedua perusahaan tersebut menunjukan bahwa kontribusi dibawah 100 milyar, sulit untuk membukukan laba positif. Sementara dengan kontribusi diatas 100 milyar, memungkinkan untuk dapat membukukan laba positif atau setidaknya tidak mengalami kerugian sejak tahun pertama PAS. Dengan demikian, acuan kesiapan spin off perusahaan berdasarkan kontribusi premi dalam penelitian ini ditentukan minimum sebesar 100 milyar rupiah.

Berdasarkan hasil peramalan kontribusi premi pada tahun 2019, unit syaariah PT ABC diproyeksikan mendapatkan kontribusi premi tahunan sebesar Rp 47,36 milyar untuk proyeksi normal dengan sensitifitas $15 \%$ sebesar Rp 40,25 milyar sampai dengan Rp 54,46 milyar. Angka ini masih setengah dari nilai acuan penelitian, sehingga sulit untuk dapat dilaksanakan spin off dalam waktu segera. Kemungkinan terbaiknya adalah dengan mengembangkan terlebih dahulu unit syariah sampai batas waktu spin off pada tahun 2024 atau melakukan spin off melalui merger dengan UUS lain.

3) Surplus Underwriting Dana Tabarru

Kecukupan dana tabarru dapat diamati berdasarkan Surplus Underwriting Dana Tabarru'. Surplus Tabarru' adalah selisih dari total kontribusi Peserta ke dalam Dana Tabarru' setelah dikurangi pembayaran klaim, kontribusi reasuransi dan penyisihan cadangan teknis, dalam satu periode. Penyisihan cadangan teknis sebagai upaya untuk memenuhi kecukupan dana tabarru' dalam membayar klaim dimasa yang akan datang dalam rentang waktu periode polis aktif.

Kecukupan dana tabarru dapat diamati dari Surplus Underwriting Dana Tabarru' positif. Hal ini sesuai dengan peraturan OJK mengenai kesehatan keuangan perusahaan Asuransi syariah 
dimana disyaratkan bahwa Surplus Underwriting Dana Tabarru' wajib positif.

Hasil peramalan Surplus UW Tabarru menunjukan bahwa Surplus dalam posisi positif (Surplus tahun 2018 Rp 1,3 milyar dan tahun 2019 Rp 1.5 milyar). Proyeksi surplus UW Tabarru mengalami koreksi dari tahun 2017 sebesar Rp 2,0 milyar atau terkoreksi turun 34,21\%. Surplus UW tabarru diproyeksikan mengalami kenaikan kembali paada tahun 2019 sehingga menjadi $\mathrm{Rp}$ 1,5 milyar atau mengalami peningkatan sebesar $11.15 \%$ dari tahun 2018. Diagram surplus UW tabarru setelah peramalan sebagai berikut:

Diagram 3. Surplus UW Tabarru dan Peramalan Surplus UW Tabarru

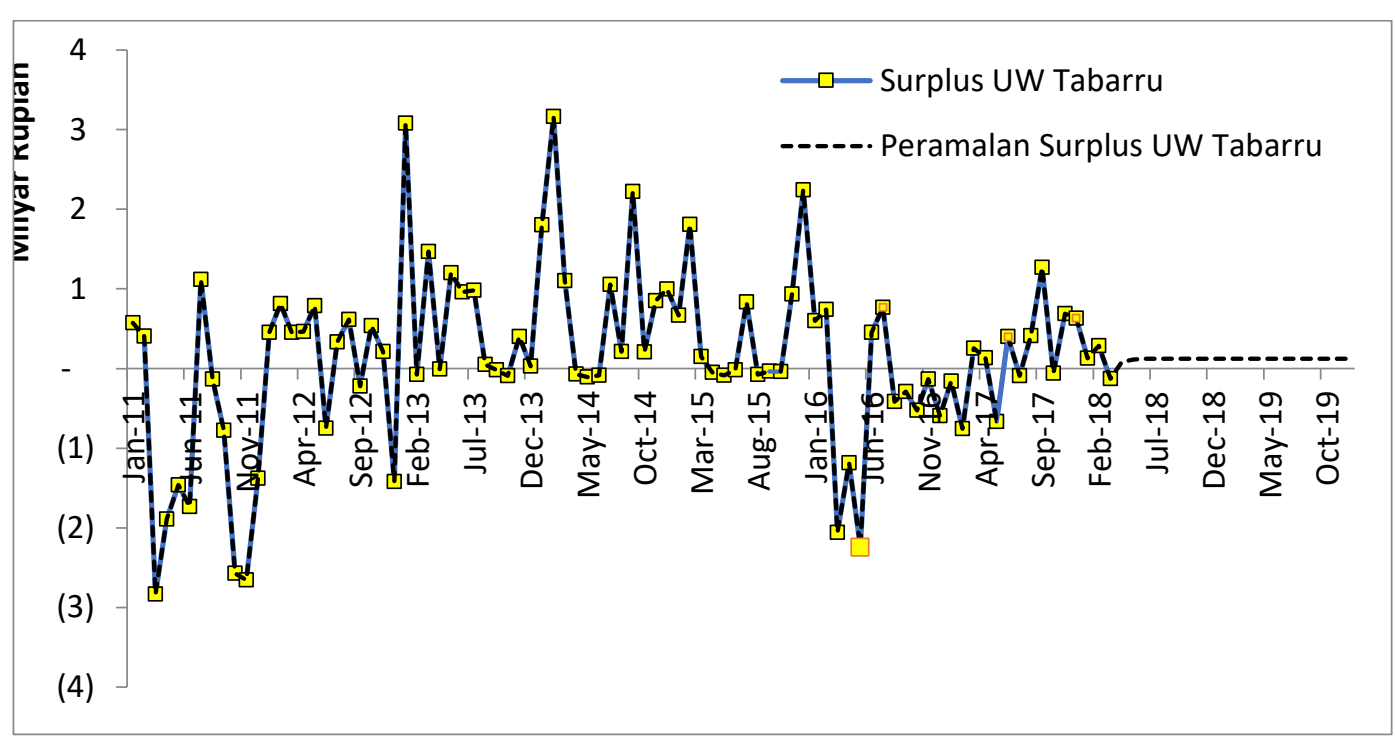

Berdasarkan cross validation dapat diamati bahwa peramalan surplus uw tabarru mempunyai nilai MAD Rp 54,99 juta atau MAPE 13,98\%. Nilai tersebut menunjukan bahwa validitas model peramalan masih rendah. Hal ini sangat mungkin terjadi mengingat fluktuasi surplus uw tabarru bulanan sangat tinggi. Fluktuasi ini bisa diakibatkan oleh beberapa hal diantaranya adanya klaim atas satu polis dengan nominal klaim premi yang besar atau Dana Tabarru belum mencapai bilangan besar (large number) sehingga belum stabil.

Berdasarkan kondisi saat ini dan hasil peramalan, dapat diamati bahwa Surplus UW Dana Tabarru' dalam kondisi positif sehingga tidak ada kekhawatiran atas kecukupan dana tabarru' dalam pelaksanaan spin off. Nominal Surplus 
tidak menjadi ukuran selama positif, walaupun surplus yang besar akan dapat menambah pendapatan perusahaan dari bagi hasil mudhorobah bagian pengelola serta kemampuan untuk ekspansi pada produk baru.

Nominal Surplus UW Tabarru yang masih kecil menjadi perhatian terkait kemampuannya menghadapi kemungkinan risiko terjadinya klaim retensi sendiri yang besar (high severity) seperti total loss pada kendaraan, kebakaran gedung atau lainnya. Selain itu, kondisi dimana terdapat klaim kecil dalam jumlah yang banyak (high frequency) pun menjadi perhatian. Dengan demikian, kondisi surplus uw tabarru positif adalah salah satu pertimbangan baik dalam kesiapan spin off, dengan tetap melihat pertumbuhan surplus dimasa yang akan datang.

\section{E. KESIMPULAN}

Berdasarkan peramalan dan pembahasan atas ketiga variable penelitian, dapat disimpulkan hal-hal sebagai berikut :

1. Perkembangan UUS PT ABC menunjukan perkembangan yang positif. Ekuitas menunjukan peningkatan dan kesiapan dalam memenuhi kebutuhan minimum atas modal PAS hasil spin off, serta Surplus UW Tabarru menunjukan angka positif yang menunjukan kecukupan dana Tabarru'. Namun demikian, untuk kontribusi premi, walaupun menunjukan peningkatan tetapi nominalnya masih kecil.

2. UUS PT ABC masih mempunyai prospek untuk dapat memenuhi kewajiban spin off pada tahun 2024. Namun untuk dapat spin off mandiri tanpa merger atau akuisisi masih perlu diamati kembali beberapa tahun kedepan.

3. Dengan mempertimbangkan beberapa kelebihannya, merger menjadi pilihan strategi yang lebih reliable dalam proses spin off unit syariah PT ABC. Namun apabila dalam beberapa tahun mendatang, potensi perkembangan kontribusi premi meningkat signifikan, tidak menutup kemungkinan untuk spin off mandiri.

4. Skala ekonomi tertentu atas kemungkinan pendapatan ujroh dari kontribusi premi serta opex, tetap menjadi pertimbangan dalam keputusan spin off dalam menjaga keberlangsungan usaha. 


\section{DAFTAR PUSTAKA}

Depatemen Agama - RI. (1999). AlAur'an-terjemahan. Depatemen Agama - RI.

Adib, Bahari. (2010). Prosedur Cepat Mendirikan Perseroan Terbatas. Yogyakarta: Pustaka Yustisia.

Adriana, Dadi dan Yos Sunitiyoso. (2013). Developing a Differentation Strategy of a Captive Insurance Companies Case Study of PT XYZ. The Indonesia Journal Of Business Administration, 2(4).

Ali, AM. Hasan. (2013). Asuransi dalam Perspektif Hukum Islam. AsySyari'ah, 41(1): 134.

Dewi, Gemala. (2007). Aspek-Aspek Hukum dalam Perbankan dan Perasuransian Syariah di Indonesia. Jakarta: Kencana Prenada Media Grup.

Fatwa DSN-MUI Nomor 21/DSNMUI/X/2001 tentang Pedoman Umum Asuransi Syariah.

Ghofur Abdul, Dasopang. (2016). Tinjauan Yuridis Ketentuan Hukum Yang Mengatur Tentang Persiapan Spin Off (Study Kasus Kewajiban Spin Off Asuransi Jiwa Bersama Bumiputera Syariah). Thesis.

Gujarati, Damodar N. (2004). Basic Econometrics. Eight Edition. Singapore: Mc Graw-Hill.

Heizer, Jay dan Render, Barry. (2009). Manajemen Operasi, Buku 1 Edisi 9. Jakarta: Salemba Empat.

Herjanto, Eddy. (2008). Manajemen Operasi, Edisi Ketiga. Jakarta: Grasindo.
Iqbal, Muhaimin. (2005). Asuransi Umum Syariah dalam Praktik. Jakarta: PT Gema Insani Press.

Kurniasari, Amanda. (2017). Analisis Perbandingan Kinerja Keuangan Bank Syariah Sebelum dan Sesudah Spin-Off.

Lohy, Yonalthia, (2017). Peramalan Penerimaan Pajak Hotel Dengan Metode Runtun Waktu - ARIMA. Thesis: ITS Surabaya.

Manan, Abdul. (2012). Hukum Ekonomi Syariah: Dalam Perspektif Kewenangan Peradilan Agama. Jakarta: Kencana.

Melynda. (2012). Penetapan Strategy Pemasaran Berdasarkan Forecast Penjualan Produk Yoghurt di PT Sukanda Djaya. Thesis: Universitas Esa Unggul.

Murahartawaty. (2009). Peramalan. Jakarta: STT Telkom.

Nurfadilah, Sindi dkk. (2015). Analisis Rasio Keuangan Dan Risk Based Capital Untuk Menilai Kinerja Keuangan Perusahaan Asuransi: Studi pada PT. Asei Reasuransi Indonesia Periode 2011-2013. Jurnal Administrasi Bisnis Universitas Brawijaya, 22(1).

R. A Sabrina. (2012). An Analysis of The Corporate Spin Offs in Indonesia: Potential, Regulations and Issues. Master Thesis: Tilburg University.

Ramdhani, Herry. (2015). Prospek Dan Tantangan Perkembangan Asuransi Syariah di Indonesia. AL-TIJARY, 01(01).

Rival, Veitzhal et al. (2007). Bank and Financial Institution Management Conventional and Syari'ah System. Jakarta: PT. RajaGrafindo Persada. 
Sula, Muhammad Syakir. (2004). Asuransi Syariah (Life and General): Konsep dan Sistem Operasional. Jakarta: Gema Insani.

Sundari, Retno Ika. (2016). Kinerja Merger Dan Akuisisi Pada Perusahaan Go Public. Telaah Bisnis, 17(1).
Syahatah, Husain. (2006). Asuransi dalam Perpektif Syariah. Jakarta: AMZAH.

Voesenek, A.A. (2014). The Effects of Mergers and Acquisitions on Firm Performance, An international comparison between the non-crisis and crisis period. Master Thesis: Tilburg School of Economics and Management. Netherland. 
Ad-Deenar: Jurnal Ekonomi dan Bisnis Islam, VOL: 5/NO: 02 DOI : 10.30868/ad.v5i02.1681
P-ISSN: 2356-1866

E-ISSN: 2614-8838 